\title{
Academic Dishonesty/ Corruption in the Period of Technology: Its implication for Quality of Education
}

\author{
Mebratu Mulatu Bachore* \\ Department of Languages and Communication Studies, College of Social Sciences and Humanities, Hawassa University, Ethiopia \\ *Corresponding author: mebratumulatu@yahoo.com
}

Received October 23, 2014; Revised November 10, 2014; Accepted November 12, 2014

\begin{abstract}
Cheating has reached alarming proportions in all segments, creating widespread cynicism and an erosion of trust. The root of the problem can be found in our schools, where academic dishonesty is rampant. We, academic communities, are in deep trouble if young people, students, maintain these habits as the next generation. The advancement of technologies, such as cell phones, iPods, internets, has broadened the ways by which people can achieve the goal of cheating. Traditional methods of detection may no longer be wholly successful in fully preventing cheating in examinations. New strategies need to be considered and employed to better manage the advancement of technology use for illegitimate purposes. Therefore, this review article will thoroughly discuss the nature of academic dishonesties (traditional and the 'modern' ones), their causes, their diverse natures, the shift from traditional to modern era and measures to be applied to shape the values and attitudes of young people engage in thoughtful, systematic and comprehensive efforts to promote integrity and prevent cheating, especially compatible with the advancement of technology.
\end{abstract}

Keywords: academic integrity, corruption, technology, quality education

Cite This Article: Mebratu Mulatu Bachore, "Academic Dishonesty/ Corruption in the Period of Technology: Its implication for Quality of Education.” American Journal of Educational Research, vol. 2, no. 11 (2014): 1060-1064. doi: 10.12691/education-2-11-9.

\section{What Does Academic Dishonesty/ Plagiarism Constitute?}

Academic institutions are places where citizens are prepared for a diverse need of life and societal issues. We value academic integrity very highly and do not permit any forms of dishonesty or deception that unfairly, improperly or illegally enhance a grade on an individual assignment or a course grade. We are aware, however, that new forms of cheating, plagiarism and other forms of dishonesty may arise and therefore, we expect every student to interpret the requirement of academic honesty and integrity broadly and in good faith.

Plagiarism occurs when a person represents someone else's words, ideas, phrases, sentences, or data as one's own work (Higbee \& Thomas, 2002). When submitting work that includes someone else's words, ideas, syntax, data or organizational patterns, the source of that information must be acknowledged through complete, accurate and specific references. All word for word statements must be acknowledged through quotation marks, unless, academic dishonesty comes as a practice in the academic environment.

\section{Forms of Academic Dishonesty}

In the academic environment, academic dishonesty can be explained in different ways. In most cases, in Ethiopia, the practices are being manifested in the form of cheating exams and plagiarism (papers and assignments). Moreover, they can be classified as traditional and modern forms by considering the gradual shift in the advancement of new technologies.

\subsection{Exam Cheating Vs Plagiarism}

Academic dishonesty may be categorized as exam cheating and plagiarism based on the nature of the acts. In cheating exams, Etter et. al (2006) state that we can have a list of activities including copying from others, having or using notes, formulas or other information in a programmable calculator or other electronic device without explicit teacher review and permission, having or using a communication device such as a cell phone, pager, or electronic translator to send or obtain unauthorized information, taking an exam for another student, or permitting someone else to take a test for someone else and asking another to give you improper assistance, including offering money or other benefits and etc.

Secondly, under plagiarism, practices like, giving or getting improper assistance on an assignment meant to be individual work, including in any assignment turned in for credit any materials not based on your own research and writing; this includes: using the services of a commercial term paper company, using the services of another student and copying part or all of another person's paper and submitting it as your own for an assignment. In addition, acting as a provider of paper(s) for a student or students, 
submitting substantial portions of the same academic work for credit in more than one course without consulting both teachers (self-plagiarism), failing to properly acknowledge paraphrased materials via textual attribution, footnotes, endnotes and/or a bibliography and citing nonexistent sources (articles, books, etc.) are seriously considered as acts of plagiarism.

In the Ethiopian context, though there are differences in the widespread of the acts, both forms of dishonesties are observed in the academic institutions. However, experiences revealed that the former one is prevalent in all academic levels. The later one, plagiarism, is very common in higher education: universities and colleges.

\subsection{Traditional Vs. Modern Academic Dishonesty}

According to Kevin (2011), this is a classification which is based on the type of the materials the students use. That means their level of advancement and application relatively in a short period of time with minimum degree of identification.

Traditional ways/ techniques are relatively cheaper and accessible in the academic institutions regardless of life standard of the individual student. The most common forms are four (Williams, 2010). The first one is pencil case which students could keep their pencil case on their desk. Cheaters in this case could hide notes within their pencil case to aid them during the examination. A pencil case was also used in other ways. The other strategy is hiding notes. Students can also hide notes on their person. This could be in their school jacket or even in their socks. When the exam moderators are not looking, they could then take a peek at their notes. The third technique is writing on arms/hands/ rulers. Here the student writes notes on the inside and back of their arms \& hands. This has faded away a little. It is also difficult to disguise in the exam hall and there is limited space on the body to supply the information required. The final example is leaving the room. A student could ask to go to the toilet at anytime where they can then look at notes and return to the examination hall. This method obviously had a downfall, this being that it is not possible to go to the toilet frequently.

On the other hand, modern forms include different technologically sophisticated methods supported by latest inventions. Students commonly exploit for techniques. Mobile phones are the most commonly used ones. A student could use a mobile phone to text someone on the outside to get the answer. This would be difficult in a typical exam hall although many students would be able to text without looking at the mobile phone. The person sitting on the outside would be at a computer to quickly look up the answer and text the student back. The second technology based apparatus used for cheating is Calculator. Scientific calculators can store formulas, fractions and text. The modern calculators, for instance, provide preloaded periodic table (highly advantageous for students taking science exams), a history feature which would allow a cheater to look back on calculations that they made at home and exam answers can also be loaded directly onto the calculator via USB. MP 3 Players are also used for sophisticated cheating. An MP3 player such as the iPod shuffle is easy to disguise as it is small and the lead of the earphones can be hidden below clothing. Finally, wireless receivers are among the frequently used ones. A wireless microphone can also be used to cheat in an exam. This device is combined and used with wireless earphones. To cheat using the microphone, the student would have to whisper the question into the microphone. To cheat using the microphone, the student would have to whisper the question into the microphone. This would then be picked up by someone outside of the exam hall who would look up the answer and then say it into a microphone which would be broadcast into the earphones of the student (Lewenson et al., 2005; Brown, 2002).

\section{Experiences Call for Academic Integrity}

In 2012, a graduating class student was assigned as an adviser to a friend of mine to carry out his BA degree graduation requirement senior essay project. They (student and advisor) talked how to conduct the project. In the mean time, he refused to see his advisor in the given period of time, and finally, he came up with a complete work and requested the advisor to approve. When the advisor looked in to it, it was his (the advisor's) BA graduation senior essay project in 2007.

In 2010, I was assigned as an advisor to a graduating class lady as advisor. First, she told me her title which she was about conduct the project and we agreed. Later, she came up with a proposal. After looking it critically, I appointed her to discuss. During the discussion, she requested me to write all the comments in a piece of paper rather than talking with her. Few days later, she came with a smart proposal by including all the points. Whenever I talked about points of further improvements, she told me that she wanted it in a written form. Finally, I realized that she was not working by herself, and asked her to tell me the bare fact. After hesitating for some time, she told me that there was someone who was paid money to incorporate all the comments from my advisor.

The above two real experiences are only some from thousands. They equally convey a message that how academic dishonesty should be a critical concern in environments where citizens are being ready to take social responsibilities. The challenges of academic dishonesty do not only apply to undergraduate students, but doctorallevel researchers may be poorly advised and may have insufficient experience in the domain field. If students plagiarize outside their Ph.D. advisors' own area of expertise, lapses may not be easily discoverable (Mitchell \& Carroll, 2008).

\section{Studies Conducted on Cheating and Plagiarism}

There are a number of studies which have been conducted in various academic institutions across the world. The studies disclosed different forms of plagiarism are rampant in the institutions. In addition, they identified the extent of epidemic, and the factors which have contributed for its wider dissemination.

One of the most important studies in this article is the work of McCabe and Treviño's (1993) which is a survey 
of more than 6,000 students at 31 academic institutions. It disclosed the strong influence of peers' behavior which may suggest that academic dishonesty not only is learned from observing the behavior of peers, but that peers' behavior provides a kind of normative support for cheating. The fact that others are cheating may also suggest that, in such a climate, the non-cheater feels left at a disadvantage. Thus, cheating may come to be viewed as an acceptable way of getting and staying ahead. McCabe et al.'s (1999) qualitative study supported these findings and identified other factors that can influence cheating, including pressure to get high grades, parental pressures, a desire to excel, pressure to get a job, laziness, a lack of responsibility, a lack of character, poor self-image, a lack of pride in a job well done, and a lack of personal integrity.

Some scholars further investigated the factors contributed for plagiarism (Higbee \& Thomas, 2002). They categorize them as external and internal (institutional). External factors are related to competition affect academic dishonesty. These may include pressures to achieve good grades, test anxiety, the classroom environment and relative risk of detection, institutional policies on academic honesty, and performance and achievement issues.

In terms of internal factors, Higbee \& Thomas, 2002 and Angell, 2006 found some potential links to personality constructs. Demographic factors do not apparently affect whether or not a student will engage in academic misconduct, with researchers finding little or no correlation between academic dishonesty and ethnicity, or academic dishonesty and religious beliefs. Those with higher grade point averages (GPAs) tend to be less likely to cheat. Older, non-traditional students tend to cheat less than their younger counterparts. Others suggest that such situational factors as "the pressure to succeed in school, external work commitments, heavy course loads, and financial aid or scholarship requirements" (Carpenter, Harding, Finelli, Montgomery \& Passow, 2006) have little effect on academic dishonesty.

On the other hand, various studies have been conducted on the 'Why' of academic corruption. The complexity of the issue of academic dishonesty becomes evident from the diversity of reasons students offer for why they cheat. Researchers argue students cheat due to ignorance (Jocoy, 2006), poor professors and teaching environments (Sterngold, 2004), inadequate policies and penalties regarding academic dishonesty (Macdonald \& Carroll, 2006), peer influence (Brown, 2002), to improve grades (Cummings et al., 2002), opportunity (DiCarlo, 2007), the Internet, underdeveloped moral reasoning (Lewenson et al., 2005), the need to get a good job; and a cheating culture (Langlais, 2006; Callahan Sterngold, 2004).

\section{The Role of Technology in Academic Corruption}

Recent literature suggests that the internet and technology play a role in the increased number of students who are involving in cheating. Researchers found a positive correlation between academic dishonesty and the increased use of technology in education (Harper, 2006). Computers and other high tech equipment have changed the way people communicate, work, study, and carry out health care. The prevalence of digital resources provides an environment where academic dishonesty such as cut and paste plagiarism can be extremely easy.

Hinman, a professor of philosophy who researches the impact of the internet on students, categorized students into three groups - the first group would never cheat, the second plans and continuously cheats, and the third group, comprising 70 to $80 \%$ of students, do not plan to cheat but may end up doing so in the face of time constraints or other issues. He identifies this third group most at risk for internet dishonesty (Williams, 2010). This is supported by a 2004 study (Underwood \& Szabo) that found 94\% of students were sufficiently experienced with the internet to use it for cutting and pasting resources. Students were accepting of internet dishonesty with 50\% saying they would use it to cheat to avoid a failing grade (Underwood \& Szabo, 2004). Szabo and Underwood found that the majority of students were sufficiently skilled to cheat using the internet, with $32 \%$ admitting to plagiarizing using internet resources and almost $8 \%$ cheating this way more than once per week.

\section{Strategies to Curb Plagiarism}

Studies have suggested various ways to control academic dishonesty. The most common ones are the technologies themselves and the stakeholders. Technologically based online environments may also be designed to lessen academic dishonesty. Some testing systems have built-in "misuse detection" or "plagiarism detection.” Others use computer forensics to track student work. Some use key logger spyware and sniffers (Mitchell, T. \& Carroll, J. (2008) to detect academic dishonesty; others use watermarking to discover the actual audit trails of exchanged code in a computer coding course.

Universities, colleges and school need to more clearly explain the rationale for promoting academic honesty and integrity in lab or research work. Many argue that this critical value needs to be supported from the top with its authoritative allocation at the level of presidents, boards, and accrediting associations. Leaders need to bring in all elements on campus to align behind the academic integrity policy, to avoid some of the blame-shifting that may occur regarding academic dishonesty (McCabe, 2005). This reveals that a holistic institutional approach may be most effective.

To be effective, the social norms intervention requires consistency, depth and breadth. These norms relate to core values of the community (Carpenter, Harding, Finelli, \& Mayhew, 2005). Notions of independent thinking, intellectual property, the struggle of original thought, and academic freedom are all at risk should dishonesty prevail over integrity warn researchers. Widespread abuses of academic integrity may lead to endemic corruption (Crittenden, Hanna, \& Peterson, 2009). At universities, a reputation for poor academic honesty will dilute degrees and potentially threaten accreditation.

On the other hand, faculty members play an important role in a university's academic integrity policy. Faculty need to build communities where "the learning is emphasized over measures of academic achievement” and where role models who "do not cut corners" are lauded. Learners need to be inoculated against pro-plagiarism 
justifications through rational and cognitive reasons to build up attitudinal resistance). Researchers have pointed out people's ability to both engage in academic dishonesty but still consider themselves honest people (Mazar, Amir, \& Ariely, 2008).

\begin{tabular}{|c|c|c|}
\hline Cheating Method & Method Detection & Method Prevention \\
\hline $\begin{array}{l}\text { Cell - texting: type out a text message to } \\
\text { someone else in class (or even at home) and } \\
\text { get silent text reply }\end{array}$ & Watch for cell phone usage of any kind & Prohibit cell phones in test environment \\
\hline $\begin{array}{c}\text { Cell - photo: take photo of test question, } \\
\text { send to someone at home, get silent text } \\
\text { reply }\end{array}$ & Watch for cell phone usage of any kind & Prohibit cell phones in test environment \\
\hline $\begin{array}{l}\text { Calculator - program: type formulas or } \\
\text { cheats into calculator before test begins }\end{array}$ & $\begin{array}{c}\text { Patrol room frequently; watch for frantic clearing } \\
\text { of calculator results; watch for "flipping } \\
\text { through" calculator readout }\end{array}$ & $\begin{array}{l}\text { Prohibit calculators in test environment; OR ask } \\
\text { department to invest in a box of "simple" } \\
\text { calculators to share for tests }\end{array}$ \\
\hline $\begin{array}{c}\text { Calculator - sharing: program cheats ahead } \\
\text { of time and let someone else use the } \\
\text { calculator during the test }\end{array}$ & Watch for sharing of calculators & $\begin{array}{l}\text { Prohibit calculators in test environment; OR ask } \\
\text { department to invest in a box of "simple" } \\
\text { calculators to share for tests }\end{array}$ \\
\hline $\begin{array}{c}\text { iPod - professor: listen to recorded lecture } \\
\text { during the test; possible to hide earphone } \\
\text { wires behind long hair }\end{array}$ & Scan for earphone wires; patrol room nonstop & $\begin{array}{l}\text { Prohibit iPod usage; require devices to be placed } \\
\text { into backpack below desk }\end{array}$ \\
\hline $\begin{array}{l}\text { iPod - student: prerecord yourself saying } \\
\text { formulas and cheats; listen during test }\end{array}$ & Scan for earphone wires; patrol room nonstop & $\begin{array}{l}\text { Prohibit iPod usage; require devices to be placed } \\
\text { into backpack below desk }\end{array}$ \\
\hline
\end{tabular}

(Kevin Yee and Patricia MacKown, 2010:8)

\section{The Implications to Quality of Education}

The quality of Education is the great concern of the Ethiopian government these days. Scholars of education underscore the students' assessment strategies as core part in insuring quality. In reality, student assessment should be regarded as a complex, multidimensional activity that requires alignment, balance and rigor assessment in order to assure quality outcomes (Joughin, \& Macdonald, 2004). To ensure rigorous assessment, academic cheating must be minimized. Academic cheating is a violation of academic integrity (Kitahara, Westfall, \& Mankelwicz, 2011).

Academic cheating can occur at either the institutional or individual level. In institutional cheating, a higher education institution might attempt to inflate scores, perhaps to ensure that its students do well. This might happen on transnational programmes where the awarding body is an external service provider. In such a case, it is in the interest of the local service provider to inflate scores so as to maintain market share. However, the negative impact on quality will be significant if the awarding body or the accrediting body does not have a rigorous quality assurance system to limit such practices in the provider countries.

Similarly, Brimble and Stevenson-Clarke (2005) stated the implications of academic dishonesty on the quality of educations in three directions. Firstly, it threatens the equity and efficacy of instructional measurement, so that students' relative abilities are not accurately evaluated; and secondly, students who cheat probably reduce their level of learning so they are less prepared for advanced study or application of the material presented in a course. At the broader, societal level, it is likely that students who do not respect academic integrity while at university will not respect integrity in their future professional and personal relationships.

In General, the practices of academic dishonesty are real threats to quality because they limit the usefulness and credibility of marks and awards. The implications of this kind of corruption must be made clear, and institutions should be encouraged to develop practices that foster and develop academic integrity among students.

\section{Technology Based Classroom Academic Dishonesty and Remedies}


raising trainings should be delivered starting from early grades. In addition, parents should also be taught to shape their children in the area. Similarly, discussions should be arranged among the students about the wider threat of academic dishonesty. In line with this, the responsibilities should be shared among the stakeholders such as, teachers, students, parents, department heads, school principals, and college officials to implement the directions forwarded in different discussions so as to curb the problem successfully.

\section{References}

[1] Brimble, M., \& Stevenson-Clarke, P. Perceptions of the prevalence and seriousness of academic dishonesty in Australian universities. The Australian Educational Researcher, 32 (3), 19-44, 2005.

[2] Brown, D. L. Cheating Must Be Okay-Everybody Does It! Nurse Educator 27 (1), 6-8, 2002.

[3] Carpenter, D.D., Harding, T.S., Finelli, C.J., Montgomery, S.M., \& Passow, H.J. Engineering students' perceptions of and attitudes towards cheating. Journal of Engineering Education: 95 (3). 181194, 2006.

[4] Crittenden, V.L., Hanna, R.C., \& Peterson, R.A. Business students' attitudes toward unethical behavior: A multi-country comparison. Marketing Letters, 20 (1), 1-14, 2009.

[5] Cummings, R., Maddux, C. D., Harlow, S., \& Dyas, L. Academic Misconduct in Undergraduate Teacher Education Students and Its Relationship to Their Principled Moral Reasoning. Journal of Instructional Psychology, 29 (4), 286-296, 2002.

[6] DiCarlo, C. Personal Interview, April 12, 2007.

[7] Etter, S., Cramer, J. J., \& Finn, S. Origins of academic dishonesty: Ethical orientations and personality factors associated with attitudes about cheating with information technology. Journal of Research on Technology in Education, 39 (2), 133-155, 2006.

[8] Harper, M. High tech cheating. Nurse Education Today, 26 (8), 672-679, 2006.

[9] Higbee, J.L. \& Thomas, P.V. Student and faculty perceptions of behaviors that constitute cheating. NASPA Journal, 40 (1), 39-52, 2002.

[10] Jocoy, C. Plagiarism by Adult Learners Online: A case study in detection and remediation. The International Review of Research in Open and Distance Learning, 7 (1), 1-17, 2006.
[11] Joughin, G., \& Macdonald, R. A model of Assessment in Higher Education Institutions. The Higher Education Academy. Retrieved from

http://www.llas.ac.uk/resourcedownloads/2968/Joughin_and_Mac donald_model_assessment.pdf, 2004.

[12] Kevin Yee and Patricia MacKown. Detecting and Preventing Cheating During Exams. Center for Academic Integrity, Rutland Institute for Ethics, Clemson University. Available at http://www.academicintegrity.org, 2011.

[13] Kevin C.. Cheating in Exams with Technology. International Journal of Cyber Ethics in Education, 1 (2), 54-62, April-June 2011.

[14] Kitahara, R., Westfall, F., \& Mankelwicz, J. New, multi-faceted hybrid approaches to ensuring academic integrity. Journal of Academic and Business Ethics, Retrieved from http://www.aabri.com/ manuscripts/10480.pdf, 2011.

[15] Langlais, P. J. Ethics for the Next Generation. The Chronicle of Higher Education, 52 (19), B11, 2006.

[16] Lewenson, S. B., Truglio-Londrigan, M., Singleton, J. Practice What You Teach: A Case Study of Ethical Conduct in the Academic Setting. Journal of Professional Nursing, 21 (2), 89-96, 2005.

[17] Macdonald, R. \& Carroll, J. Plagiarism-a complex issue requiring a holistic institutional approach. Assessment \& Evaluation in Higher Education, 31 (2), 233-245, 2006.

[18] Mazar, N., Amir, O., \& Ariely, D. The dishonesty of honesty people: A theory of self-concept maintenance. Journal of Marketing Research: XLV. American Marketing Association. 633-644, 2008.

[19] McCabe, D. L. It Takes A Village: Academic Dishonesty and Educational Opportunity. Liberal Education, Summer/Fall. Retrieved on 1/27/2007 from http://www.les3.com/, 2005

[20] McCabe, D.L., Treviño, L.K., \& Butterfield, K.D. Honor codes and other contextual influences on academic integrity: A replication and extension to modified code settings. Research in Higher Education: 43 (3), 357-378, 2002.

[21] Mitchell, T. \& Carroll, J. Academic and research misconduct in the Ph.D: Issues for students and supervisors. Nurse Education Today: 28, 218-226, 2008.

[22] Sterngold, A. Confronting Plagiarism. Change, May/June 2004.

[23] Underwood J., \& Szabo A., Academic offences and e-learning: individual propensities in cheating. British Journal of Educational Technology. 34 (4), 467-477, 2004.

[24] Williams, R. Mobile phones drive increase in exam cheating. Guardian. 23 (II), 8-9, 2010. 